\title{
Electroanalytical Determination of Escitalopram Oxalate Using Nickel Nanoparticles Modified Carbon Paste Sensor
}

\author{
Ali Kamal Attia, ${ }^{1, *}$ Mona A. Mohamed ${ }^{1}$ and Amany M. Fekry ${ }^{2}$ \\ ${ }^{1}$ National Organization for Drug Control and Research, P.O. Box 29, Cairo, Egypt \\ ${ }^{2}$ Chemistry Department, Faculty of Science, Cairo University, Giza-12613, Egypt \\ * Corresponding author: E-mail: alikamal1978@ hotmail.com \\ Tel.: 002 0235851278; Fax: 0020235855582
}

Received: 10-01-2017

\begin{abstract}
A sensitive voltammetric method was described for the determination of escitalopram oxalate based on electrocatalytic oxidation at nickel nanoparticles modified chloranil carbon paste sensor in Britton-Robinson buffer ( $\mathrm{pH}$ range from 2 to 10). The modified electrode was characterized by scanning electron microscopy, electrochemical impedance and cyclic voltammetry. The investigation of electrochemical behavior of escitalopram oxalate was performed using cyclic voltammetry and differential pulse voltammetry. The anodic peak current showed a linear range from $1.0 \times 10^{-6}$ to $7.0 \times 10^{-5}$ mol L$~^{-1}$. The detection limit is below $2.0 \times 10^{-7} \mathrm{~mol} \mathrm{~L}^{-1}$. The proposed method is rapid, economical, simple, precise and sensitive voltammetric method for the determination of escitalopram oxalate in bulk, dosage form and urine.
\end{abstract}

Keywords: Escitalopram oxalate, voltammetry, nickel nanoparticles, modified electrode, urine

\section{Introduction}

Escitalopram oxalate (ESC) has high effectivity for the treatment of major depressive episodes and generalized anxiety disorders explaining its pharmacological and clinical applications. ${ }^{1-3}$

Various reported methods have been employed for determination of ESC, including chromatography, ${ }^{4-16}$ fluorimetry, ${ }^{14}$ spectrophotometry, ${ }^{15-21}$ chemiluminescence, ${ }^{22}$ capillary electrophoresis, ${ }^{23,24}$ potentiometry, ${ }^{25,26}$ and voltammetry. ${ }^{27}$

Some electron acceptor reagents such as 2,3-dichloro-5,6-dicyano-1,4-benzoquinone (DDQ), 7,7,8,8-tetracyano-quinodimethane (TCNQ), tetracyanoethylene (TCNE) and chloranil (CA) can be used in electroanalytical field as mediators or electrode modifiers. ${ }^{28-36}$

The development of nanoscale materials has been extensively used, particularly with respect to metallic nanoparticles. Interests have focused on their use in analytical chemistry because of their specific physico-chemical properties. The modified electrodes increase the selectivity and the sensitivity of electroa- nalytical processes more than the bare electrodes leading to increase in their analytical applicability. ${ }^{37-45}$ On the other hand, nanoparticles have excellent electronic and electrocatalytic properties, which accelerate the rate of heterogeneous electron exchange between the electrode surface and some species in solution and increase the effective surface area of the working electrode. ${ }^{46-54}$

The aim of this work is the study of the electrochemical behavior of ESC utilizing cyclic voltammetry (CV), differential pulse voltammetry (DPV) and electrochemical impedance spectroscopy (EIS) for the analysis of ESC in bulk powder, tablets and urine at nickel nanoparticles modified chloranil carbon paste sensor (NiCACP).

\section{Experimental}

\section{1. Materials and Reagents}

ESC was supplied by Hikma Pharmaceuticals, Egypt, and Cipralex tablets (10 mg ESC per tablet) were purchased from Multi Pharma/Lundbeck. 
DDQ, TCNQ and TCNE were obtained from Merck. $\mathrm{CA}$, nickel nitrate, graphite powder and paraffin oil were supplied by Sigma-Aldrich.

Stock solution of ESC $\left(1.0 \times 10^{-3} \mathrm{~mol} \mathrm{~L}^{-1}\right)$ was prepared by dissolving an appropriate amount in methanol. Britton-Robinson (BR) buffer was prepared by mixing phosphoric acid $\left(0.04 \mathrm{~mol} \mathrm{~L}^{-1}\right)$, acetic acid $\left(0.04 \mathrm{~mol} \mathrm{~L}^{-1}\right)$ and boric acid $\left(0.04 \mathrm{~mol} \mathrm{~L}^{-1}\right)$. The $\mathrm{pH}$ values were adjusted using $0.2 \mathrm{~mol} \mathrm{~L}^{-1} \mathrm{NaOH}$.

\section{2. Preparation of Working Electrodes}

1. Chloranil modified carbon paste electrode (CACP) was made by dissolving CA $(10 \mathrm{mg})$ in ethyl ether, then mixing with graphite powder $(990 \mathrm{mg})$ in a mortar. After evaporation of solvent, paraffin oil was added and mixed until a uniformly wetted paste was obtained. The paste was packed into the hole of the electrode and smoothed on a filter paper until it had a shiny appearance.

2. Bare carbon paste electrode $(\mathrm{CP})$ was prepared according to the above procedures without addition of CA.

3. Different modified electrodes (DDQCP, TCNECP and TCNQCP) were prepared by adding DDQ, TCNQ and TCNE instead of CA.

4. Nickel nanoparticles modified chloranil carbon paste sensor (NiCACP) was prepared by electro-deposition of nickel nanoparticles on CACP immersed in an aqueous solution of $0.1 \mathrm{~mol} \mathrm{~L}^{-1}$ acetate buffer solution of pH 4.0 containing $1.0 \times 10^{-3} \mathrm{~mol} \mathrm{~L}^{-1} \mathrm{Ni}\left(\mathrm{NO}_{3}\right)_{2}$ at -1.0 $\mathrm{V}$ vs. $\mathrm{Ag} / \mathrm{AgCl} / 3 \mathrm{~mol} \mathrm{~L}^{-1} \mathrm{NaCl}$ reference electrode for 240 s. ${ }^{5}$

\section{3. Apparatus}

AEW2 electrochemical workstation with ECProg3 electrochemistry software (Sycopel, England) was used in this study. A platinum wire (BASi model MW-1032) and an $\mathrm{Ag} / \mathrm{AgCl} / 3 \mathrm{~mol} \mathrm{~L}^{-1} \mathrm{NaCl}$ (BASi model MF-2063) were used as a counter electrode and reference electrode, respectively. The $\mathrm{pH}$ measurements were carried out utilizing a cyberscan $500 \mathrm{pH}$ meter (EUTECH Instruments, USA).

EIS was performed using IM6e electrochemical workstation (Zahner-electrik GmbH, Germany). All diagrams were recorded by applying $10 \mathrm{mV}$ sinusoidal potential within a frequency range from $100 \mathrm{kHz}$ to 100 $\mathrm{mHz}$.

Scanning electron microscopy (SEM) measurements were achieved by a JSM-6700F scanning electron microscope (Japan Electro Company, Japan).

\section{4. Determination of ESC in Bulk Powder}

The working, counter and reference electrodes were submerged in electrolytic cell containing $5 \mathrm{~mL}$ of BR buf- fer $(\mathrm{pH} 7.0)$. Aliquots of ESC $\left(1.0 \times 10^{-3} \mathrm{~mol} \mathrm{~L}^{-1}\right)$ were added, and then voltammetric analyses were carried out by using DPV method and the voltammograms were recorded at scan rate of rate of $20 \mathrm{mV} \mathrm{s}^{-1}$, pulse amplitude of $50 \mathrm{mV}$ and accumulation time of $100 \mathrm{~s}$.

\section{5. Determination of ESC in Tablets}

Ten tablets were weighed and crushed to a fine powder using mortar and pestle, and then sufficient amount to prepare $1.0 \times 10^{-3} \mathrm{~mol} \mathrm{~L}^{-1}$ ESC was transferred into 100 $\mathrm{mL}$ volumetric flask already containing $60 \mathrm{~mL}$ of methanol. The flask was sonicated for about $15 \mathrm{~min}$ and completed to the volume with methanol. The solution was filtered to remove the insoluble excipients. ESC was determined by standard addition method.

\section{6. Analysis of ESC in Urine}

Urine sample obtained from a healthy person (50 $\mathrm{mL}$ ) was stored in a refrigerator at $8.0^{\circ} \mathrm{C}$ for one week. 10 $\mathrm{mL}$ from urine sample was centrifuged for $10 \mathrm{~min}$ at 2000 $\mathrm{rpm}$. The supernatant was filtered using $0.45 \mu \mathrm{m}$ filter paper, and then diluted ten times with BR buffer of $\mathrm{pH}$ 7.0. Successive additions of ESC $\left(1.0 \times 10^{-3} \mathrm{~mol} \mathrm{~L}^{-1}\right)$ were added to the voltammetric cell containing diluted urine (5.0 $\mathrm{mL}$ ) and DPV voltammograms were listed. The experiments were performed in compliance with the Helsinki Declaration of 1975, as revised in 2008. The institutional committees (NODCAR, Egypt) have approved these experiments. Informed consent was obtained from all participants.

\section{Results and Discussion}

\section{1. Electrochemical Behavior of ESC}

The pharmaceutical and biomedical analysis is among the most important branches of applied analytical chemistry. Analytical measurement procedures should have a critical role in drug analysis as well as in biological samples. DPV method has been developed for determination of ESC in the bulk, tablets and urine using nickel nanoparticles modified chloranil carbon paste sensor.

Fig. 1a presents the cyclic voltammograms of ESC $\left(1.0 \times 10^{-4} \mathrm{~mol} \mathrm{~L}^{-1}\right)$ in BR buffer of $\mathrm{pH} 7.0$ at different working electrodes: CP, DDQCP, TCNQCP, TCNECP and $\mathrm{CACP}$, exhibiting one well defined anodic peak with no peak on the reverse scan, suggesting the irreversibility of the electrode reaction. This anodic peak may be attributed to the oxidation of tertiary amine group which agree with the reported method ${ }^{27}$ (Fig 1c).

Fig. $1 \mathrm{~b}$ describes the effect of mediator type on the anodic current of ESC in BR buffer of $\mathrm{pH}$ 7.0. The anodic peak current values are in the following order: $\mathrm{CACP}$ $(15.16 \mu \mathrm{A})<\operatorname{DDQCP}(13.02 \mu \mathrm{A})<\mathrm{TCNECP}(10.08 \mu \mathrm{A})$ 
$<$ TCNQCP $(9.29 \mu \mathrm{A})<\mathrm{CP}(6.09 \mu \mathrm{A})$. CA increases the anodic peak current from $6.09 \mu \mathrm{A}$ at $\mathrm{CP}$ to $15.16 \mu \mathrm{A}$ at $\mathrm{CACP}$ and lowers the oxidation potential from $1.147 \mathrm{~V}$ at $\mathrm{CP}$ to $1.095 \mathrm{~V}$ at $\mathrm{CACP}$, thus $\mathrm{CA}$ acts as an electrocatalytic mediator.

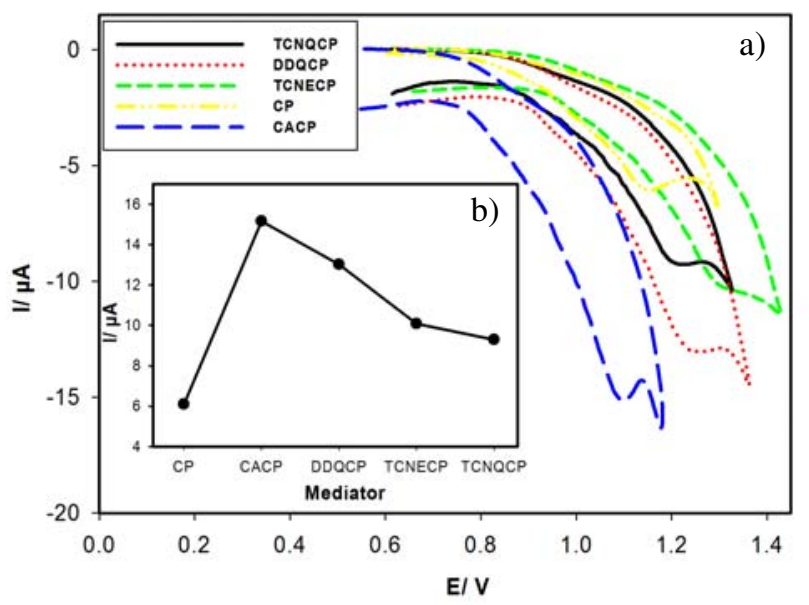

c)

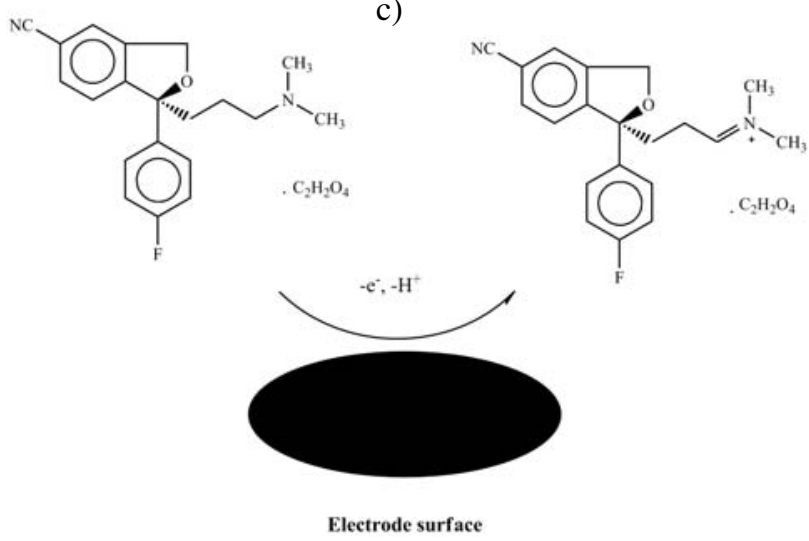

Figure 1: Cyclic voltammograms of $1.0 \times 10^{-4} \mathrm{~mol} \mathrm{~L}^{-1} \mathrm{ESC}$ in $\mathrm{BR}$ buffer of $\mathrm{pH} 7.0$ in case of CACP, DDQCP, TCNECP, TCNQCP and $\mathrm{CP}$, scan rate $100 \mathrm{mV} \mathrm{s}^{-1}$ (a). The inset: the plot of anodic current as a function of mediator type (b). The oxidation mechanism of $\mathrm{ESC}(\mathrm{c})$.

\section{2. Effect of pH}

Voltammetric behavior of ESC was studied in BR buffer over the $\mathrm{pH}$ range from 2 to 10 at $\mathrm{CACP}$ as shown in Fig. 2a. The peak current increases as the $\mathrm{pH}$ increases up to $\mathrm{pH} 7.0$, after $\mathrm{pH} 7.0$ the peak current decreases as the $\mathrm{pH}$ increases (Fig. 2b). Therefore, $\mathrm{pH} 7.0$ was selected as a suitable supporting electrolyte because the peak current reaches its maximum value at this $\mathrm{pH}$ value.

Fig. 2c demonstrates that the peak potential varies linearly with $\mathrm{pH}$ over the $\mathrm{pH}$ values (2-10) with the linear regression equation of $\mathrm{E}(\mathrm{V})=1.451-0.054 \mathrm{pH}$, with a correlation coefficient $(\mathrm{R})$ of 0.9937 . The slope was found to be $-54 \mathrm{mV} / \mathrm{pH}$ units, which is close to the theoretical value of $-59 \mathrm{mV}$ suggesting that the number of protons and transferred electrons involved in the oxidation mechanism is equal. ${ }^{56}$


Figure 2: Cyclic voltammograms of $1.0 \times 10^{-4} \mathrm{~mol} \mathrm{~L}^{-1} \mathrm{ESC}$ in $\mathrm{BR}$ buffer over the $\mathrm{pH}$ range of 2-10 at CACP, scan rate of $100 \mathrm{mV} \mathrm{s}^{-1}$ (a). Plots of anodic peak current (b) and peak potential (c) as a function of $\mathrm{pH}$.

\section{3. Effect of $\mathrm{Ni}\left(\mathrm{NO}_{3}\right)_{2}$ Concentration}

The influence of $\mathrm{Ni}\left(\mathrm{NO}_{3}\right)_{2}$ concentration on response of fabricated sensor was investigated using different concentrations of $\mathrm{Ni}\left(\mathrm{NO}_{3}\right)_{2}\left(1.0,2.0\right.$ and $3.0 \times 10^{-3} \mathrm{~mol}$ $\mathrm{L}^{-1}$ ) which were deposited at CACP at $-1.0 \mathrm{~V}$ for different times $(120,180,240$ and $300 \mathrm{~s})$. It was found that $1.0 \times$ $10^{-3} \mathrm{~mol} \mathrm{~L}^{-1} \mathrm{Ni}\left(\mathrm{NO}_{3}\right)_{2}$ and $240 \mathrm{~s}$ are the optimum concentration and deposition time used to prepare the modified sensor (NiCACP) to give the best results for the determination of ESC.

\section{4. Morphologies of Different Electrodes}

Electronic Supplementary Information 1 (ESI 1) displays the significant differences in the surface structure 
of $\mathrm{CP}, \mathrm{CACP}$ and NiCACP. The surface of $\mathrm{CP}$ was predominated by irregular shaped graphite flaks and separate layers (ESI 1A). The SEM of CACP illustrates irregular ice shaped surface (ESI 1B). The SEM of NiCACP shows a tree shaped structure, the nanoparticles appear randomly and space among them produce large surface area (ESI $1 \mathrm{C)}$.

\section{5. Electrochemical Behavior of ESC at NiCACP}

ESI $2 \mathrm{~A}$ presents the cyclic voltammograms of ESC $\left(1.0 \times 10^{-4} \mathrm{~mol} \mathrm{~L}^{-1}\right)$ at $\mathrm{CP}, \mathrm{CACP}$ and NiCACP in BR buffer of $\mathrm{pH}$ 7.0. We note that the anodic oxidation peak has the highest current and the lowest potential values $(25.03$ $\mu \mathrm{A}, 0.980 \mathrm{~V}$ ) in case of NiCACP in comparison with these values in case of CACP $(15.16 \mu \mathrm{A}, 1.095 \mathrm{~V})$ and $\mathrm{CP}$ $(6.09 \mu \mathrm{A}, 1.147 \mathrm{~V})$. NiCACP shows catalytic effect in the anodic oxidation of ESC. Therefore, it was selected to determine ESC in bulk, tablets and urine.

Scan rate $(v)$ effect on the the peak current (I) of ESC $\left(1.0 \times 10^{-4} \mathrm{~mol} \mathrm{~L}^{-1}\right)$ was carried out by immersing NiCACP in BR buffer of $\mathrm{pH} 7.0$, and the cyclic voltammograms were recorded over the scan range of 10-250 $\mathrm{mV} \mathrm{s}^{-1}$. ESI 2B shows a linear relationship between $\log \mathrm{I}$ and $\log v$ as given by the following equation: $\log \mathrm{I}=0.28$ $+0.56 \log v$. The slope of 0.56 indicates a diffusion controlled process with some adsorption character. ${ }^{57}$

Accumulation time $\left(\mathrm{T}_{\text {acc }}\right)$ effect on the peak current was studied at open circuit condition at NiCACP in BR buffer of $\mathrm{pH} 7.0$ containing $1.0 \times 10^{-4} \mathrm{~mol} \mathrm{~L}^{-1} \mathrm{ESC}$. It was found that the peak current increases as the accumulation time increases up to $100 \mathrm{~s}$ and then it decreases as $\mathrm{T}_{\text {acc }}$ increases. $100 \mathrm{~s}$ was selected as the optimum accumulation time in the determination of ESC (ESI 2C).

The electron transfer coefficient $(\alpha)$ can be calculated using the following equation: $\alpha=47.7 /\left(\mathrm{E}_{\mathrm{p}}-\mathrm{E}_{\mathrm{p} / 2}\right) \mathrm{mV},{ }^{58}$ where $E_{p}$ is the peak potential and $E_{p / 2}$ is the potential where the current is at half peak value. $\alpha$ was calculated to be 0.48 .

The standard rate constant of $\operatorname{ESC}\left(\mathrm{K}^{\circ}\right)=1.0 \times 10^{-3}$ $\mathrm{s}^{-1}$ was obtained utilizing Laviron equation: $\mathrm{Ep}=\mathrm{E}^{\circ}+$ $2.303 \mathrm{RT} / \alpha \mathrm{nF}[\log \mathrm{RTK} \% \alpha \mathrm{nF}+\log v]$, where $\mathrm{n}$ is number of electrons, $\mathrm{T}$ is the temperature $(298 \mathrm{~K}), \mathrm{R}$ the gas constant $\left(8.314 \mathrm{~J}^{-1} \mathrm{~K}^{-1} \mathrm{~mol}^{-1}\right), \mathrm{F}$ the Faraday constant $(96,485$ C.mol ${ }^{-1}$ ) and $\mathrm{E}^{\mathrm{o}}$ is the formal potential obtained by plotting the relation between $\mathrm{E}_{\mathrm{p}}$ and $v$ (extrapolating the line to $v=0),{ }^{59} \mathrm{E}^{\circ}=0.908 \mathrm{~V}, \alpha \mathrm{n}=0.537$, hence $\mathrm{n}$ was calculated to be $1.12(\mathrm{n} \approx 1)$.

The electroactive area of NiCACP was obtained by applying Randles-Sevcik equation, ${ }^{60}$ using $1.0 \times 10^{-3} \mathrm{~mol}$ $\mathrm{L}^{-1} \mathrm{~K}_{3} \mathrm{Fe}(\mathrm{CN})_{6}$ at different scan rates, the diffusion coefficient of $\mathrm{K}_{3} \mathrm{Fe}(\mathrm{CN})_{6}$ is $7.6 \times 10^{-6} \mathrm{~cm}^{2} \mathrm{~s}^{-1}$, ${ }^{61}$ the electroactive area (A) was calculated to be $0.128 \mathrm{~cm}^{2}$. The surface concentration of $\operatorname{ESC}(\Gamma)$ at NiCACP was calculated employing the following equation: $I=n^{2} F^{2} A \Gamma v / 4 R T, n=1, \Gamma$ was found to be $1.215 \times 10^{-6} \mathrm{~mol} \mathrm{~cm}{ }^{-2}{ }^{62}$

\section{6. Electrochemical Impedance Spectroscopy Study}

Nyquist plots of ESC using NiCACP and CACP exhibit the difference in the presence of metallic nickel nanoparticles as shown in Fig. 3a.

A simple equivalent circuit model (Fig. 3b) was used to fit the results. $R_{s}$ is the solution resistance and $R_{p}$ is the polarization resistance. Q represents the constant phase element (CPE) of capacitance for the film, $n$ is its corresponding empirical exponents, $\mathrm{C}_{\mathrm{f}}$ is the capacitance of the double layer and $\mathrm{W}$ is the Warburg impedance due to diffusion (Table 1). The capacitance value for NiCACP is relatively higher than CACP in terms of $\mathrm{C}_{\mathrm{f}}$ and $\mathrm{Q}$ denoting the increase of ionic adsorption at the electrode/electrolyte interface for NiCACP. Moreover, the decrease in the $R_{p}$ is attributed to the selective interaction between nickel nanoparticles and ESC that resulted in the increase of the current in the electro-oxidation process.

NiCACP stability was studied in BR buffer of $\mathrm{pH}$ 7.0 containing $1.0 \times 10^{-4} \mathrm{~mol} \mathrm{~L}^{-1} \mathrm{ESC}$ as a function of immersion time (Fig. 3c). The results show good stability till $12 \mathrm{~h}$, thus NiCACP works well.
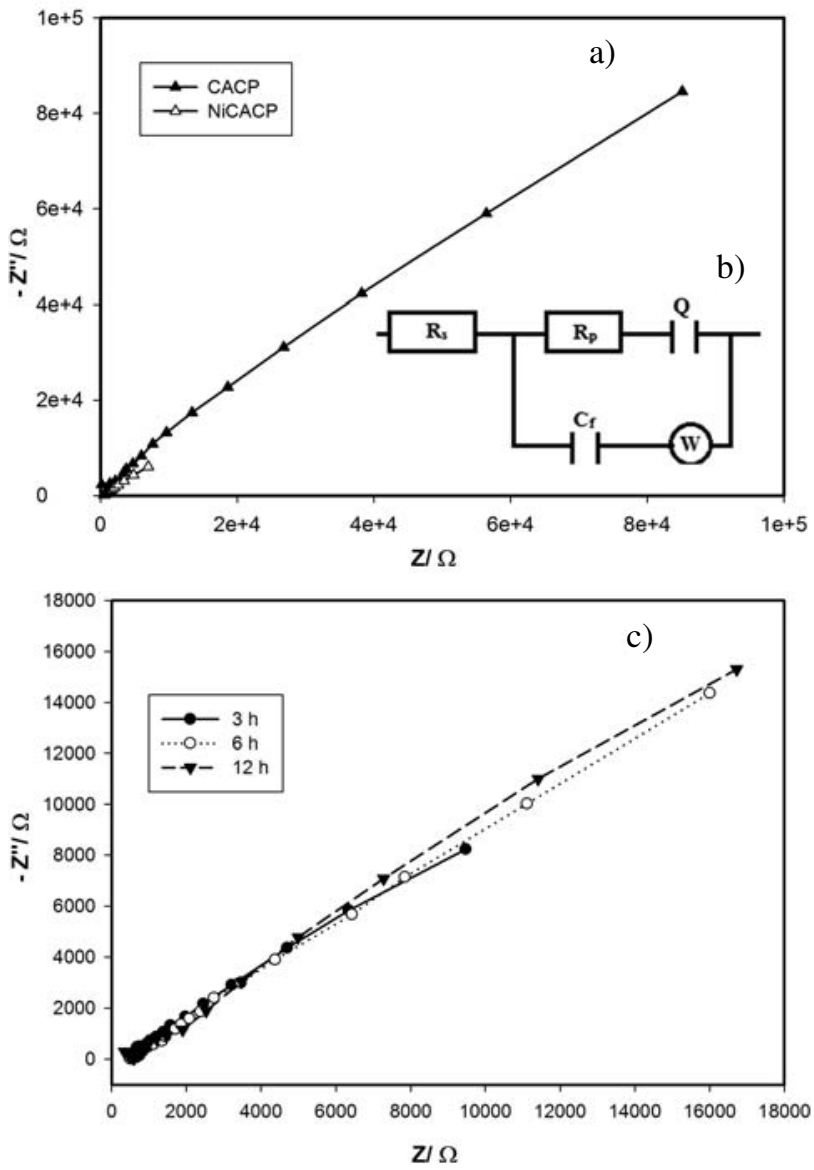

Figure 3: Nyquist plots of NiCACP and CACP in BR buffer $\mathrm{pH} 7.0$ containing $1.0 \times 10^{-4} \mathrm{~mol} \mathrm{~L}^{-1}$ ESC solution (a). Equivalent circuit for Nyquist plot (b). Nyquist plot of NiCACP in BR buffer $\mathrm{pH} 7.0$ containing $1.0 \times 10^{-4} \mathrm{~mol} \mathrm{~L}^{-1} \mathrm{ESC}$ solution as a function of immersion time (c). 
Table 1: Fitting data of electrochemical impedance spectroscopy.

\begin{tabular}{lcccccc}
\hline Electrode & $\mathbf{R}_{\mathbf{S}} / \mathbf{k} \boldsymbol{\Omega} \mathbf{~ c m}^{\mathbf{2}}$ & $\mathbf{R}_{\mathbf{p}} / \mathbf{k} \boldsymbol{\Omega} \mathbf{~ c m}^{\mathbf{2}}$ & $\mathbf{Q} / \boldsymbol{\mu} \mathbf{F} \mathbf{~ c m}^{-\mathbf{2}}$ & $\mathbf{n}$ & $\mathbf{C}_{\mathbf{f}} / \boldsymbol{\mu} \mathbf{F ~} \mathbf{~ m}^{-\mathbf{2}}$ & $\mathbf{W} / \mathbf{K} \boldsymbol{\Omega} \mathbf{s}^{-\mathbf{1}}$ \\
\hline NiCACP & 0.35 & 312 & 27 & 0.81 & 15 & 43 \\
CACP & 0.35 & 4587 & 10.1 & 0.85 & 3.5 & 415 \\
\hline
\end{tabular}

\section{7. Determination of ESC in Bulk Powder}

DPV method was applied for quantitative analysis of ESC in $5.0 \mathrm{~mL}$ of BR buffer (pH 7.0) at NiCACP. Successive additions from ESC solution $\left(1.0 \times 10^{-3} \mathrm{~mol} \mathrm{~L}^{-1}\right)$ were introduced into the electrolytic cell and the voltammograms were recorded, giving linearity over the concentration range of $1.0 \times 10^{-6}-7.0 \times 10^{-5} \mathrm{~mol} \mathrm{~L}^{-1}(0.414-$ $29.01 \mu \mathrm{g} \mathrm{m}^{-1}$ ) as shown in Fig. 4.

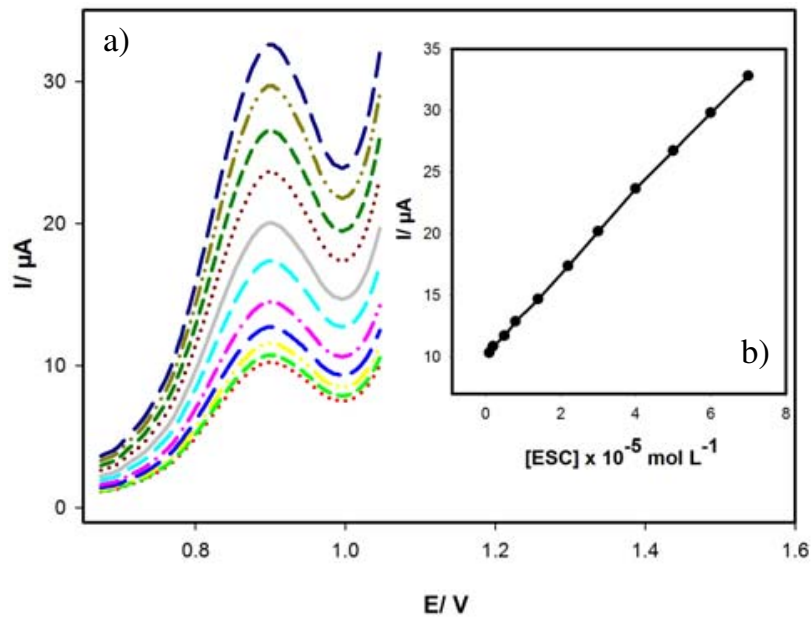

Figure 4: Calibration curve of ESC at NiCACP, pulse amplitude = $50 \mathrm{mV}, \mathrm{T}_{\text {acc }}=100 \mathrm{~s}$ and scan rate $=20 \mathrm{mV} \mathrm{s}^{-1}$ (a). Plot of anodic current as a function of ESC concentration (b).

The validation of the method was performed according to the International Conference on Harmonization (ICH) guideline, ${ }^{63}$ through the evaluation of limit of detection (LOD), limit of quantification (LOQ), precision, accuracy, ruggedness and robustness. The LOD and LOQ were found to be $1.98 \times 10^{-7} \mathrm{~mol} \mathrm{~L}^{-1}$ and $6.60 \times 10^{-7} \mathrm{~mol} \mathrm{~L}^{-1}$, respectively. The relative standard deviation (RSD) and the percentage recovery values were found in the following ranges: $0.33-0.77 \%$ and $99.91-101.35 \%$, respectively.

The proposed method is more sensitive than some reported methods such as chromatographic methods: 20-120 $\mu \mathrm{g} \mathrm{mL}^{-1},{ }^{10} 50-300 \mu \mathrm{g} \mathrm{mL}^{-1},{ }^{11} 80-120 \mu \mathrm{g} \mathrm{mL}^{-1},{ }^{12}$ 2-20 $\mu \mathrm{g} \mathrm{mL}^{-1},{ }^{13} 10-60 \mu \mathrm{g} \mathrm{mL}^{-1},{ }^{15}$ and $10-50 \mu \mathrm{g} \mathrm{m}^{-1},{ }^{16}$ spectrophotometric methods: $10-50 \mu \mathrm{g} \mathrm{mL} \mathrm{m}^{-1},{ }^{16} 2-20 \mu \mathrm{g}$ $\mathrm{mL}^{-1},{ }^{17} 2-10 \mu \mathrm{g} \mathrm{mL}{ }^{-1},{ }^{18} 5-100 \mu \mathrm{g} \mathrm{mL}{ }^{-1},{ }^{19} 0.50-8.00 \mu \mathrm{g}$ $\mathrm{mL}^{-1},{ }^{20}$ and $20-120 \mu \mathrm{g} \mathrm{mL}{ }^{-1},{ }^{21}$ and electrochemical method: $150-400 \mu \mathrm{g} \mathrm{mL} .^{27}$

The ruggedness of the method was done through the analysis of $1.0 \times 10^{-5} \mathrm{~mol} \mathrm{~L}^{-1}$ ESC by two different analysts with the percentage recovery values of $99.94 \%$ and
$100.30 \%$ for the first and the second analyst, respectively. Hence, the results show good agreement.

The robustness of the method was examined by testing the influence of small variations from the optimum conditions: $\mathrm{pH}(7.00 \pm 0.20)$, scan rate $(20 \pm 2.00)$ and accumulation time $(100 \pm 5.00)$ on the peak current of $\operatorname{ESC}(1.00 \times$ $\left.10^{-5} \mathrm{~mol} \mathrm{~L}^{-1}\right)$. The RSD values were $0.35 \%, 0.58 \%$ and $0.42 \%$ for $\mathrm{pH}$, scan rate and accumulation time, respectively, indicating the robustness of the proposed method.

\section{8. Interference Study}

Some interfering species $\left(1.00 \times 10^{-3} \mathrm{~mol} \mathrm{~L}^{-1}\right)$ such as inorganic cations $\left(\mathrm{Na}^{+}, \mathrm{K}^{+}\right.$, and $\left.\mathrm{Ca}^{2+}\right)$, sugars (glucose and dextrose) and amino acid (valine and alanine) were used to study their interference with ESC $\left(1.00 \times 10^{-3} \mathrm{~mol}\right.$ $\mathrm{L}^{-1}$ ). There is no interference between these species and ESC; NiCACP shows good selectivity for the determination of ESC.

\section{9. Analysis of ESC in Tablets}

Standard addition method was successfully applied to determine ESC in Cipralex tablets at NiCACP without any pretreatment or time consuming extraction steps prior to analysis. The mean recovery and mean RSD values for five replicate measurements were $100.58 \%$ and $1.18 \%$, respectively. The results listed in Table 2 show there is no interference between ESC and the excipients suggesting the selectivity and the sensitivity of the proposed method in the determination of ESC in dosage forms.

Table 2: Determination of ESC in Cipralex tablets by applying standard addition technique.

\begin{tabular}{lcccr}
\hline $\begin{array}{l}\text { Dosage } \\
\text { form }\end{array}$ & $\begin{array}{c}\text { ESC } \\
\left(\mathbf{m o l ~ L}^{-1}\right) \\
\text { Taken }\end{array}$ & \multicolumn{2}{c}{$\begin{array}{c}\text { ESC }\left(\mathbf{m o l ~ L}^{-\mathbf{1}}\right) \\
\text { Added }\end{array}$} & $\begin{array}{c}\text { Recovery } \\
(\%)\end{array}$ \\
\hline Cipralex & $8.00 \times 10^{-6}$ & $4.00 \times 10^{-6}$ & $12.15 \times 10^{-6}$ & 101.25 \\
tablets & & $8.00 \times 10^{-6}$ & $15.96 \times 10^{-6}$ & 99.75 \\
& & $12.00 \times 10^{-6}$ & $20.11 \times 10^{-6}$ & 100.55 \\
& & $16.00 \times 10^{-6}$ & $24.18 \times 10^{-6}$ & 100.75 \\
\multicolumn{2}{c}{ Mean recovery $\pm \mathrm{RSD}^{*} \%$} & \multicolumn{3}{c}{$100.58 \pm 1.18$} \\
\hline
\end{tabular}

$*$ Number of replicates $(\mathrm{n})=5$.

\section{10. Analysis of ESC in Urine}

The proposed method was used to determine ESC in urine samples (ESI3) in concentration range of $4.00 \times$ 
$10^{-6}-6.00 \times 10^{-5} \mathrm{~mol} \mathrm{~L}^{-1}$ with correlation coefficient of 0.9998 , the LOD and LOQ were $7.57 \times 10^{-7} \mathrm{~mol} \mathrm{~L}^{-1}$ and $2.52 \times 10^{-6} \mathrm{~mol} \mathrm{~L}^{-1}$, respectively. Four different concentrations $\left(8.00 \times 10^{-6}, 2.20 \times 10^{-5}, 3.60 \times 10^{-5}\right.$, and $4.40 \times$ $10^{-5} \mathrm{~mol} \mathrm{~L}^{-1}$ ) were chosen to be repeated five times to evaluate the accuracy and precision of the method. The RSD and the percentage recovery values were in the following ranges: $0.41-0.89 \%$ and $99.38-101.94 \%$, respectively.

The proposed method is more sensitive than chromatographic method used to determine ESC in urine $\left(22.80 \times 10^{-5} \mathrm{~mol} \mathrm{~L}^{-1}\right) .{ }^{64}$ The proposed method is less sensitive than capillary electrophoresis method $\left(1.496 \times 10^{-9}\right.$ $-1.61 \times 10^{-6} \mathrm{~mol} \mathrm{~L}^{-1}$ ) but our method is more simple, cheap and it is used to determine ESC in urine without any extraction steps or pretreatment. ${ }^{24}$

\section{Conclusion}

It is important to determine drugs at higher sensitivity than in the reported methods, therefore it was our intention to develop a precise and sensitive electroanalytical voltammetric method for the determination of ESC. The use of chloranil as modifier and Ni nanoparticles increases the active sites at the electrode surface which increases the sensitivity toward ESC. The proposed method is more sensitive than some reported methods as mentioned before in the text, thus it is an excellent means for determination of ESC in quality control because of its low cost, accuracy, selectivity and enforcement. The proposed method can be applied in clinical laboratories and pharmacokinetic studies.

\section{Acknowledgment}

The authors would like to express their gratitude to the National Organization for Drug Control and Research (NODCAR, Egypt) for providing instruments and the means necessary to accomplish this work.

\section{References}

1. W. J. Burke, Expert Opin. Investig. Drugs, 2002, 11, 14771486. https://doi.org/10.1517/13543784.11.10.1477

2. C. Sanchez, K. P. Bogeso, B. Elbert, E. H. Reines, and C. Braestrup, Psychopharmacology (Berl.), 2014, 174, 163176.

3. M. A. Margoob, D. Mushtaq, I. Murtaza, H. Mushtaq, and A. Ali, Indian J. Psychiatry, 2008, 50, 47-50. https://doi.org/10.4103/0019-5545.39759

4. M. V. Mahadik, S. R. Dhaneshwar, and M. J. Kulkarni, Eurasian J. Anal.. Chem., 2007, 2, 101-117.

5. N. Dhavale, S. Gandhi, S. Sabnis, and K. Bothara, Chromatographia, 2008, 67, 487-490. https://doi.org/10.1365/s10337-008-0524-7

6. C. Greiner, C. Hiemke, W. Bader, and E. Haen, J. Chromatogr. B, 2007, 848, 391-394.

https://doi.org/10.1016/j.jchromb.2006.10.058

7. S. B. Syama, and A. Suneetha, Int. J. Pharm. Bio. Sci., 2011, 2, 140-146.

8. B. Raman, B. A. Sharma, P. D. Ghugare, S. Nandavadekar, D. Singh, P. K. Karmuse, and A. Kumar, J. Pharm. Biomed. Anal., 2010, 53, 895-901.

9. M. S. Charde, Int. J. Pharm. Chem., 2012, 2, $23-26$.

10. C. N. Bhimanadhuni, D. R. Garikapati, and P. Usha, Int. Curr. Pharm. J., 2012, 1, 193-198.

11. T. Samanta, S. Dey, H. B. Samal, D. B. Kumar, D. L. M. Mohanty, and K. Bhar, Int. J. Chem. Res., 2011, 2, 11-15.

12. A. Chanda, N. Ramalakshmi, C. N. Nalini, S. Arunkumar, and S. Mahabubi, IAJPR, 2016, 6, 5622-5629.

13. N. Rahul, G. Vaibhavi, and D. K. Vilasrao, IAJPR, 2015, 5, 2497-2502.

14. E. A. Taha, N. N. Salama, and S. Wang, Anal. Chem. Insights, 2009, 4, 1-9. https://doi.org/10.4137/ACI.S2274

15. S. V. Gandhi, N. D. Dhavale, V. Y. Jadhav, and S. S. Sabnis, J. AOAC Int., 2008, 91, 33-38.

16. S. C. Patel, and D. G. Maheshwari, AJPTI, 2016, 4, 59-70.

17. S. Sharma, H. Rajpurohit, C. Sonwal, A. Bhandari, V. R. Choudhary, and T. Jain, J. Young Pharm., 2010, 2, 420-423. https://doi.org/10.4103/0975-1483.71626

18. T. Vetrichelvan, K. Arul, M. Sumithra, and B. Umadevi, Indian J. Pharm. Sci., 2010, 72, 269-271. https://doi.org/10.4103/0250-474X.65011

19. R. B. Kakde, and D. D. Satone, 2009, 71, 702-705. https://doi.org/10.4103/0250-474X.59559

20. K. M. Al-Ahmary, Int. J. Pharm. Chem., 2012, 2, 121-125.

21. S. Pinki, D. Patel, D. Meshram, and S. Desai, IAJPR, 2016, 6, 4544-4553.

22. N. A. Alarfaj, F. A. Aly, and A. A. Al-Qahtany, Luminescence, 2013, 28, 84-92. https://doi.org/10.1002/bio.2372

23. B. Sungthong, P. Jac, and G. K. E. Scriba, J. Pharm. Biomed. Anal., 2008, 46, 959-965. https://doi.org/10.1016/j.jpba.2007.05.029

24. N. Johannesson, and J. Bergquist, 2007, 43, 1045-1048. https://doi.org/10.1016/j.jpba.2006.09.008

25. F. M. G. Al-Amri, N. A. Alarfaj, and F. A. Aly, Int. J. Electrochem. Sci., 2013, 8, 10044-10058.

26. A. F. Khorshid, $U K J P B, \mathbf{2 0 1 4}, 2$, 9-21.

27. R. Jain, Dhanjai, and S. Sharma, Colloids Surf. A, 2013, , 178-184. https://doi.org/10.1016/j.colsurfa.2013.06.007

28. O. R. Luca, T. Wang, S. J. Konezny, V. S. Batista, and R. H. Crabtree, New J. Chem., 2011, 35, 998-999. https://doi.org/10.1039/c0nj01011a

29. S. A. M. Refaey, A. A. Hassan, and H. S. Shehata, Int. J. Electrochem. Sci., 2008, 3, 325-337.

30. Y. Hanyu, and I. Honma, J. Mater. Chem., 2011, 21, 9154 9159. https://doi.org/10.1039/c1jm00026h

31. R. Ojani, J. B. Raoof, and S. Zamani, Electroanalysis, 2005, 17, 1740-1745. https://doi.org/10.1002/elan.200503277

32. A. A. Ensafi, M. Dadkhah, and H. K. Maleh, 2011, 84, 
148-154. https://doi.org/10.1016/j.colsurfb.2010.12.028

33. A. K. Attia, and M. A. Elshal, Anal. Bioanal. Electrochem., 2012, 4, 213-224.

34. A. A. Ensafi, A. Arabzadeh, and H. K. Maleh, J. Braz. Chem. Soc., 2010, 21,1572-1580. https://doi.org/10.1590/S0103-50532010000800024

35. H. K. Maleh, M. A. Khalilzadeh, Z. Ranjbarha, H. Beitollahi, A. A. Ensafi, and D. Zareyee, Anal. Methods, 2012, 4, 2088-2094. https://doi.org/10.1039/c2ay05865k

36. H. Yaghoubian, V. S. Nejad, and S. Roodsaz, Int. J. Electrochem. Sci., 2010, 5, 1411-1421.

37. M. A. Mohamed, N. S. Abdelwahab, and C. E. Banks, Anal. Methods, 2016, 8, 4345-4353. https://doi.org/10.1039/C6AY00454G

38. N. N. Salama, S. M. Azab, M. A. Mohamed, and A. M. Fekry, $R S C$ Adv., 2015, 5, 14187-14195.

39. H. M. Ahmed, M. A. Mohamed, and W. M. Salem, Anal. Methods, 2015, 7, 581-589. https://doi.org/10.1039/C4AY02450H

40. D. Yang, L. Wang, Z. Chen, M. Megharaj, and R. Naidu, Electrochim Acta, 2014, 132, 223-229. https://doi.org/10.1016/j.electacta.2014.03.147

41. S. Tajik, M. A. Taher, and H. Beitollahi, Sens. Actuators B, 2014, 197, 228-236. https://doi.org/10.1016/j.snb.2014.02.096

42. A. K. Attia, W. M. Salem, and M. A. Mohamed, Acta Chim. Slov., 2015, 62, 588-594. https://doi.org/10.17344/acsi.2014.950

43. B. Nigovic, M. Sadikovic, and M. Sertic, Talanta, 2014, 122, 187-194. https://doi.org/10.1016/j.talanta.2014.01.026

44. Y. Liu, G. Su, B. Zhang, G. Jiang, and B. Yan, Analyst, 2011, 136, 872-877. https://doi.org/10.1039/c0an00905a

45. Y. Oztekin, A. Ramanaviciene, and A. Ramanavicius, Electroanalysis, 2011, 23, 701-709. https://doi.org/10.1002/elan.201100121

46. A. K. Attia, A. M. Badawy, and S. G. Abd-Elhamid, RSC Adv., 2016, 6, 39605-39617.

47. M. A. Sultan, A. K. Attia, M. M. Abou El-Alamin, and M. A. Atia, WJPPS, 2016, 5, 93-108.

48. R. A. Ahmed, and A. M. Fekry, Int. J. Electrochem. Sci., 2013, 8, 6692-6708.

49. M. H. Mashhadizadeh, and E. Afshar, Electrochim Acta, 2013, 87, 816-823. https://doi.org/10.1016/j.electacta.2012.09.004

50. J. Tashkhourian, M. R. H. Nezhad, J. Khodavesi, and S. Javadi, J. Electroanal. Chem., 2009, 633, 85-91. https://doi.org/10.1016/j.jelechem.2009.04.028

51. H. Heli, M. Hajjizadeh, A. Jabbari, and A. A. M. Movahedi, Anal. Biochem., 2009, 388, 81-90. https://doi.org/10.1016/j.ab.2009.02.021

52. C. M. Welch, and R. G. Compton, Anal. Bioanal. Chem., 2006, 384, 601-619. https://doi.org/10.1007/s00216-005-0230-3

53. H. Ibrahim, and Y. Temerk, Sens. Actuators B, 2015, 206, 744-752. https://doi.org/10.1016/j.snb.2014.09.011

54. M. A. Mohamed, A. K. Attia, and H. M. Elwy, Electroanalysis, 2017, 29, 506-513.

https://doi.org/10.1002/elan.201600311

55. A. M. Fundo, and L. M. Abrantes, J. Electroanal. Chem., 2007, 600, 63-79. https://doi.org/10.1016/j.jelechem.2006.03.023

56. I. G. David, D. E. Popa, A. A. Calin, M. Buleandra, and E. E. Iorgulescu, Turk. J. Chem., 2016, 40, 125-135. https://doi.org/10.3906/kim-1504-42

57. D. K. Gosser: Cyclic Voltammetry Simulation and Analysis of Reaction Mechanism, NewYork, USA: VCH, 1993.

58. A. J. Bard, L. R. Faulkner, J. Leddy, and C. G. Zoski. Electrochemical methods: Fundamentals and Applications, Wiley, New York, 1980.

59. E. Laviron, J. Electroanal. Chem. Interfacial Electrochem., 1979, 101, 19-28. https://doi.org/10.1016/S0022-0728(79)80075-3

60. B. R. Eggins,. Chemical Sensors and Biosensors, John Wiley \& Sons, Ltd, UK, 2003.

61. J. Xia, Z. Wang, F. Cai, F. Zhang, M. Yang, W. Xiang, S. Bi, and R. Gui, , 2015, 5, 39131-39137.

62. L. Fotouhi, M. Fatollahzadeh, M. M. Heravi, Int. J. Electrochem. Sci., 2012, 7, 3919 -3928.

63. ICH, Stability Testing of New Drug Substances and Products. International Conference on Harmonization, IFPMA, Geneva, 1993.

64. A. Salomone, D. Di Corcia, E. Gerace, and M. Vincenti, J. Anal. Tox., 2011, 35, 519-523.

https://doi.org/10.1093/anatox/35.7.519

\section{Povzetek}

Opisujemo občutljivo voltametrično metodo za določanje escitalopram oksalata, ki temelji na elektrokatalitski oksidaciji v Britton-Robinsonovem pufru ( $\mathrm{pH}$ območje 2 do 10) na senzorju iz ogljikove paste s kloranilom, modificirane $\mathrm{z}$ nikljevimi nanodelci. Modificirano elektrodo smo okarakterizirali z vrstično elektronsko mikroskopijo, elektrokemijsko impedanco in ciklično voltametrijo. Raziskavo elektrokemijskega obnašanja escitalopram oksalata smo izvedli s ciklično voltametrijo in diferencialno pulzno voltametrijo. Maksimalni anodni tok je imel linearno območje od $1,0 \times$ $10^{-6}$ do $7,0 \times 10^{-5} \mathrm{~mol} \mathrm{~L}^{-1}$. Meja zaznave je pod 2,0 $\times 10^{-7} \mathrm{~mol} \mathrm{~L}^{-1}$. Predlagana metoda je hitra, ekonomična, preprosta, točna in občutljiva voltametrična metoda za določanje escitalopram oksalata $\mathrm{v}$ farmacevtskem produktu, farmacevtskih oblikah in v urinu. 